\title{
Medikamentvalg ved hypertensjon
}

\author{
Ulike medikamenter har ulik effekt på kardiovaskulære endepunkter når blodtrykket reduseres til omtrent \\ samme nivå. Fire store randomiserte, kontrollerte kliniske studier viser at hemmere av renin-angiotensin- \\ systemet og kalsiumkanalblokkere alene eller i kombinasjon gir best effekt. Preparater i disse medikament- \\ gruppene bør derfor være førstevalg i behandling av hypertensjon.
}

Iskemisk hjertesykdom er vanligste dødsårsak i verden og viktigste årsak til tap av funksjonsjusterte leveår. Hypertensjon er den viktigste risikofaktoren for død av kardiovaskulær årsak (1). Manglende systolisk blodtrykkskontroll ses hos omtrent halvparten av dem som behandles for hypertensjon, og andelen er høyere hos pasienter med diabetes eller nyresvikt, til tross for bruk av flere medikamenter (2).

LIFE, VALUE, ASCOT og ACCOMPLISH er store hypertensjonsstudier som er publisert de seneste årene (tab 1) (3-9). I samtlige har man sammenliknet effekten av ulike blodtrykksmedikamenter på kardiovaskulær sykelighet og dødelighet, men det primære endepunktet ble definert noe ulikt. I alle studiene var behandlingsmålet et blodtrykk på under 140/90 mm Hg. Alle har minst $80 \%$ statistisk styrke til å vise $15-20 \%$ reduksjon i primært endepunkt.

I LIFE-studien sammenliknet man behandling med angiotensin II-reseptorantagonist med betablokkerbehandling. Angiotensin II-reseptorantagonist ga 14,6\% relativ risikoreduksjon i primært endepunkt (hjerneslag, hjerteinfarkt eller kardiovaskulær død) (3). Spesielt var effekten stor hos pasienter med diabetes og isolert systolisk hypertensjon (4). I gruppen som fikk angiotensin II-reseptorantagonist var det også færre som utviklet atrieflimmer (5).

I VALUE-studien fant man at samlet kardiovaskulær sykelighet og dødelighet (hjerteinfarkt, hjertesvikt, perkutan koronar intervensjon, plutselig hjertedød eller død etter hjertekirurgi) var lik hos pasienter behandlet med angiotensin II-reseptorantagonist og kalsiumkanalblokker (6), men det ble oppnådd større blodtrykksreduksjon initialt med kalsiumkanalblokker. Det var færre tilfeller av hjerteinfarkt i gruppen som fikk kalsiumkanalblokker (6), mens det i gruppen som fikk angiotensin II-reseptorantagonist var færre som utviklet ny atrieflimmer (7) og diabetes (6).

\section{Kombinasjonsbehandling}

I ASCOT-studien ga kombinasjonsbehandling med kalsiumkanalblokker med eventuelt tillegg av ACE-hemmer (angiotensinkonvertasehemmer) færre ikke-dødelige hjerteinfarkt og reduksjon i dødelig koronarsykdom sammenliknet med betablokker med eventuelt tillegg av tiazid. Studien ble avsluttet tidligere enn planlagt pga. lavere dødelighet i gruppen som fikk kalsiumkanalblokker og ACE-hemmer. Dette behandlingsregimet ga også redusert kardiovaskulær dødelighet samt færre hjerneslag enn behandling med betablokker og tiazid (8).

Resultater fra ACCOMPLISH-studien viste at kombinasjonsbehandling med kalsiumkanalblokker og ACE-hemmer var et bedre alternativ enn kombinasjonen ACEhemmer og tiaziddiuretika for reduksjon av kardiovaskulære hendelser, med $20 \%$ relativ risikoreduksjon i primært endepunkt (kardiovaskulær død, ikke-dødelig hjerteinfarkt eller hjerneslag, hospitalisering pga. angina pec- toris, gjenopplivning etter hjertestans eller koronar revaskularisering) (9).

Kombinasjonsbehandling er ofte nødvendig ved behandling av hypertensjon der det er høy tilleggsrisiko eller trykk over $160 / 100 \mathrm{~mm} \mathrm{Hg}$. Slik behandling ser ut til å gi bedre etterlevelse og lavere kostnader samt raskere og bedre blodtrykkskontroll og anbefales i europeiske retningslinjer (10). Kombinasjonen ACE-hemmer og angiotensin II-reseptorantagonist kan dog gi flere bivirkninger, uten at det gir ytterligere kardiovaskulær beskyttelse, og anbefales ikke (10). Om angiotensin II-reseptorantagonist i kombinasjon med kalsiumkanalblokker er en effektiv kombinasjon for kardiovaskulær forebygging, blir undersøkt i en stor pågående studie (11).

\section{Pasienter med $ø \mathbf{k t}$ kardiovaskulær risiko}

Pasienter med diabetes er en viktig undergruppe av hypertensjonspasienter, ettersom de har høyere kardiovaskulær risiko enn populasjonen for øvrig. Målblodtrykket er nylig justert i europeiske retningslinjer til under 140/80 - $85 \mathrm{~mm} \mathrm{Hg}$ ved diabetes $(10,12)$, mens i de overnevnte studiene var 130/80 mm Hg satt som mål for denne gruppen. I både LIFE-, VALUE- og ASCOT-studien var det færre som utviklet diabetes i gruppene som ble behandlet med hemmere av renin-angiotensin-systemet $(3,6,13,14)$. Resultatene for pasienter med diabetes i ASCOT- og ACCOMPLISH-

Tabell 1 De fire store randomiserte, kontrollerte studiene der man har sammenliknet effekten av ulike blodtrykksmedikamenter

\begin{tabular}{|c|c|c|c|c|c|}
\hline Studie & Tidsperiode & $\begin{array}{c}\text { Antall } \\
\text { pasienter }\end{array}$ & Deltakerland & Medikamenter & Hovedresultat \\
\hline LIFE (3-5) & $1995-2001$ & 9193 & $\begin{array}{l}\text { Norden, } \\
\text { Storbritannia } \\
\text { og USA }\end{array}$ & $\begin{array}{l}\text { Angiotensin II-reseptorantagonist } \\
\text { versus betablokker }\end{array}$ & $\begin{array}{l}\text { Angiotensin II-reseptorantagonist > } \\
\text { betablokker }\end{array}$ \\
\hline VALUE $(6,7)$ & $1997-2004$ & 15200 & $\begin{array}{l}\text { Norden, } \\
\text { Europa, USA, } \\
\text { Argentina, } \\
\text { Brasil, Asia } \\
\text { og Australia }\end{array}$ & $\begin{array}{l}\text { Angiotensin II-reseptorantagonist } \\
\text { versus kalsiumkanalblokker }\end{array}$ & $\begin{array}{l}\text { Angiotensin } \| \text {-reseptorantagonist = } \\
\text { kalsiumkanalblokker }\end{array}$ \\
\hline ASCOT (8) & $1998-2005$ & 19257 & $\begin{array}{l}\text { Norden, } \\
\text { Storbritannia } \\
\text { og Irland }\end{array}$ & $\begin{array}{l}\text { Kalsiumkanalblokker } \pm \\
\text { ACE-hemmer versus betablokker } \pm \\
\text { diuretika }\end{array}$ & $\begin{array}{l}\text { Kalsiumkanalblokker } \pm \text { ACE-hemmer > } \\
\text { betablokker } \pm \text { diuretika }\end{array}$ \\
\hline ACCOMPLISH (9) & $2003-08$ & 11506 & $\begin{array}{l}\text { Norden } \\
\text { og USA }\end{array}$ & $\begin{array}{l}\text { ACE-hemmer + kalsiumkanal- } \\
\text { blokker versus ACE-hemmer + } \\
\text { hydroklortiazid }\end{array}$ & $\begin{array}{l}\text { ACE-hemmer + kalsiumkanalblokker > } \\
\text { ACE-hemmer + hydroklortiazid }\end{array}$ \\
\hline
\end{tabular}


studien var omtrent som for hovedpopulasjonen. Europeiske retningslinjer anbefaler oppstart med ACE-hemmer eller angiotensin II-reseptorantagonist hos hypertensive diabetikere (10). Deretter kan hvilket som helst preparat legges til, men resultatene fra ACCOMPLISH-studien taler for at kalsiumkanalblokker bør velges som medikament nr. 2 fremfor tiaziddiuretika (15).

Pasienter med kronisk nyresykdom har spesielt høy risiko for kardiovaskulære hendelser. Hos denne pasientgruppen anbefaler europeiske retningslinjer nå kun et blodtrykk på under 130/90 mm Hg, men ved proteinuri (>1g/døgn) kan et blodtrykk på under 130/90 mm Hg etterstrebes, så lenge eGFR monitoreres (10). ACE-hemmere og angiotensin II-reseptorantagonister er bedre enn andre medikamenter til å redusere proteinuri og forsinke utvikling av nyresvikt, uansett etiologi (16). Nyresviktbehandlingen bør derfor alltid inkludere en av disse selv ved normalt blodtrykk dersom proteinuri er til stede (16). Kombinasjonsbehandling med ACE-hemmer og angiotensin II-reseptorantagonist kan gi redusert glomerulær filtrasjonshastighet og hyperkalemi og anbefales ikke $(10,17,18)$. I ACCOMPLISH-studien var det langsommere utvikling av nyresvikt hos pasienter med kronisk nyresykdom i gruppen som fikk ACE-hemmer og kalsiumkanalblokker enn i gruppen som fikk ACE-hemmer og tiazid, men det var ingen forskjell dersom årsaken var diabetesnefropati (19). Hos pasienter med normal nyrefunksjon viste ACCOMPLISH-studien at ACE-hemmer heller bør kombineres med kalsiumkanalblokker enn med tiazid med tanke på å forhindre utvikling av kronisk nyresykdom (19).

\section{Bør være førstevalg}

Nyere hypertensjonsstudier med individuell statistisk styrke viser at behandling med hemmere av renin-angiotensin-systemet og/eller kalsiumkanalblokkere gir lavere kardiovaskulær sykelighet og dødelighet enn behandling med tiazid og/eller betablokker når blodtrykket reduseres til samme nivå. Hemmere av renin-angiotensin-systemet ser også ut til å gi mindre utvikling av diabetes og atrieflimmer samt mindre og langsommere utvikling av kronisk nyresykdom. Vi mener derfor at man bør vurdere ACE-hemmer, angiotensin II-reseptorantagonister eller kalsiumkanalblokker som førstevalg, gjerne i kombinasjon (men ikke ACE-hemmer og angiotensin II-reseptorantagonist i kombinasjon), ved behandling av hypertensjon.

Artikkelen er basert på førsteforfatters studentoppgave ved Det medisinske fakultet, Universitetet i Oslo.

\section{Marcus Schultz}

Tonje Amb Aksnes

Aud Høieggen

Sverre Erik Kjeldsen

s.e.kjeldsen@medisin.uio.no

Marcus Schultz (f. 1984) er medisinstudent ved Universitetet i Oslo.

Forfatter har fylt ut ICMJE-skjemaet og oppgir ingen interessekonflikter.

Tonje Amb Aksnes (f. 1973) er ph.d. og spesialist i kardiologi og indremedisin og medlem av styret i Norsk hypertensjonsforening. Hun er for tiden i permisjon fra Hjertemedisinsk avdeling, Oslo universitetssykehus, Ullevål.

Forfatter har fylt ut ICMJE-skjemaet og oppgir følgende interessekonflikter: Hun har mottatt foredragshonorar/reisestøtte fra AstraZeneca, MSD, Novartis og Pfizer.

Aud Høieggen (f. 1956) er spesialist i indremedisin og nyresykdommer, overlege ved nyremedisinsk avdeling, Oslo universitetssykehus, Ullevål, og førsteamanuensis ved Institutt for klinisk medisin, Universitetet i Oslo.

Forfatter har fylt ut ICMJE-skjemaet og oppgir følgende interessekonflikter: Hun har mottatt foredragshonorar fra AstraZeneca, Novartis, Amgen og St. Jude Medical.

Sverre Erik Kjeldsen (f. 1953) er indremedisiner og kardiolog. Han er professor og seksjonsoverlege ved Hjertemedisinsk avdeling, Oslo universitetssykehus, Ullevål.

Forfatter har fylt ut ICMJE-skjemaet og oppgir følgende interessekonflikter: Han har mottatt konsultasjonshonorar/forskningsstøtte/foredragshonorar fra Bayer, Medtronic, Serodus, Takeda, AstraZeneca, Pronova, MSD.

\section{Litteratur}

1. Lozano R, Naghavi M, Foreman K et al. Global and regional mortality from 235 causes of death for 20 age groups in 1990 and 2010: a systematic analysis for the Global Burden of Disease Study 2010. Lancet 2012; 380: 2095-128.

2. Gu Q, Burt VL, Dillon CF et al. Trends in antihypertensive medication use and blood pressure contro among United States adults with hypertension: the National Health And Nutrition Examination Survey, 2001 to 2010. Circulation 2012; 126: 2105-14.

3. Dahlöf B, Devereux RB, Kjeldsen SE et al. Cardiovascular morbidity and mortality in the Losartan Intervention For Endpoint reduction in hypertension study (LIFE): a randomised trial against atenolol. Lancet 2002; 359: 995-1003.

4. Kjeldsen SE, Dahlöf B, Devereux RB et al. Effects of losartan on cardiovascular morbidity and mortality in patients with isolated systolic hypertension and left ventricular hypertrophy: a Losartan Intervention for Endpoint Reduction (LIFE) substudy. JAMA 2002; 288: 1491-8.

5. Wachtell K, Lehto M, Gerdts E et al. Angiotensin II receptor blockade reduces new-onset atrial fibrillation and subsequent stroke compared to atenolol: the Losartan Intervention For End Point Reduction in Hypertension (LIFE) study. J Am Coll Cardiol 2005; 45: 712-9.
6. Julius S, Kjeldsen SE, Weber M et al. Outcomes in hypertensive patients at high cardiovascular risk treated with regimens based on valsartan or amlodipine: the VALUE randomised trial. Lancet 2004: 363: 2022-31

7. Schmieder RE, Kjeldsen SE, Julius $\mathrm{S}$ et al. Reduced incidence of new-onset atrial fibrillation with angiotensin II receptor blockade: the VALUE trial. J Hypertens 2008; 26: 403-11.

8. Dahlöf B, Sever PS, Poulter NR et al. Prevention of cardiovascular events with an antihypertensive regimen of amlodipine adding perindopril as required versus atenolol adding bendroflumethiazide as required, in the Anglo-Scandinavian Cardiac Outcomes Trial-Blood Pressure Lowering Arm (ASCOT-BPLA): a multicentre randomised controlled trial. Lancet 2005; 366: 895-906.

9. Jamerson K, Weber MA, Bakris GL et al. Benazepril plus amlodipine or hydrochlorothiazide for hypertension in high-risk patients. N Engl J Med 2008; 359: 2417-28

10. Mancia G, Fagard R, Narkiewicz K et al. 2013 ESH/ ESC Guidelines for the management of arterial hypertension. Blood Press 2013; 22: 193-278.

11. Ma L, Wang W, Zhao Y et al. Combination of amlodipine plus angiotensin receptor blocker or diuretics in high-risk hypertensive patients: a 96-week efficacy and safety study. Am J Cardiovasc Drugs 2012; 12: 137-42.

12. Perk J, De Backer G, Gohlke H et al. European Guidelines on cardiovascular disease prevention in clinical practice (version 2012). The Fifth Joint Task Force of the European Society of Cardiology and Other Societies on Cardiovascular Disease Prevention in Clinical Practice lconstituted by representatives of nine societies and by invited experts). Eur Heart J 2012: 33: 1635-701.

13. Kjeldsen SE, Julius S, Mancia G et al. Effects of valsartan compared to amlodipine on preventing type 2 diabetes in high-risk hypertensive patients: the VALUE trial. J Hypertens 2006; 24: 1405-12.

14. Östergren J, Poulter NR, Sever PS et al. The Anglo-Scandinavian Cardiac Outcomes Trial: blood pressure-lowering limb: effects in patients with type II diabetes. J Hypertens 2008; 26: 2103-11.

15. Weber MA, Bakris GL, Jamerson K et al. Cardiovascular events during differing hypertension ther apies in patients with diabetes. J Am Coll Cardiol 2010; 56: 77-85

16. Sarafidis PA, Khosla N, Bakris GL. Antihypertensive therapy in the presence of proteinuria. Am J Kidney Dis 2007; 49: 12-26.

17. Yusuf S, Teo KK, Pogue J et al. Telmisartan, ramipril, or both in patients at high risk for vascular events. N Engl J Med 2008: 358: 1547-59.

18. Mann JFE, Schmieder RE, McQueen M et al. Renal outcomes with telmisartan, ramipril, or both, in people at high vascular risk (the ONTARGET study): a multicentre, randomised, double-blind, controlled trial. Lancet 2008; 372: 547-53.

19. Bakris GL, Sarafidis PA, Weir MR et al. Renal outcomes with different fixed-dose combination therapies in patients with hypertension at high risk for cardiovascular events (ACCOMPLISH): a prespecified secondary analysis of a randomised controlled trial. Lancet 2010; 375: 1173-81.

Mottatt 6.3. 2013, første revisjon innsendt 16.4. 2013, godkjent 1.7. 2013. Medisinsk redaktør Hanne Støre Valeur.

> Se også side 1792

Publisert først på nett. 